\title{
CARTOGRAPHIC IMAGE OF LAND USE CHANGES IN THE BIALA NIDA CATCHMENT SINCE THE BEGINNING OF THE 19TH CENTURY
}

DOI: https://doi.org/10.18509/GBP210037b

UDC: 528.93:502.22(438)"18/20"

\author{
Agnieszka Biskupska \\ Tomasz Kalicki \\ Ewa Nowak \\ Department of Geomorphology and Geoarchaeology, Institute of Geography and Environmental \\ Sciences Jan Kochanowski University in Kielce, Poland
}

\begin{abstract}
The last centuries have been characterized by rapid civilization progress and intensified social and economic changes. Anthropogenic activities (e.g. agriculture, industry, urbanization) and physical-geographic processes contribute to changes in land use. Proper land use from the human needs point of view, combined with the environmental potential and the protection of resources, is a fundamental problem of geographical and social sciences. The aim of this study is to identify changes in land use and land cover occurring in the catchment area of the Biała Nida river since the beginning of the 19th century, as well as an attempt to determine the causes of these changes. The essence of research is also to determine how these changes may take place in the near future. The scope of study included analysis of data obtained as a result of objects vectorization, located on raster, historical cartographic materials, subjected to calibration process. Spatial analysis methods, being a part of GIS technology, were used in the research. The conclusions drawn from the analyses of land-use changes in the Biała Nida catchment municipality are based on qualitative and quantitative evaluation. Results of the spatial analysis indicate that in the southern part of catchment area the agricultural method of land use dominates (along with fishing), while in the northern part the industry is more important (formerly metallurgy in the Old Polish Industrial District, now limestone mining and cement industry).
\end{abstract}

Keywords: land use changes, Biała Nida catchment, cartographic materials, spatial analysis, GIS

\section{STUDY AREA}

The Biała Nida catchment (Świętokrzyskie and Silesian Voivodships), with an area of over $1020 \mathrm{~km} 2$, is located in Palaeozoic structures of the Kielce Uplands, Mesozoic structures of the Przedbórz Uplands and Cretaceous structures of the Nida Basin [1]. In the catchment area it is possible to find rocks from different epochs, from Cambrian to Holocene. Deposits of limestone, marl, dolomite, sand, peat, calcite, clay, gravel, loess and barite were documented in the studied area [2]. From the 12th/13th century, the catchment area was exploited for its raw materials, i.e. silver, copper and lead. Iron production was possible thanks to the occurrence of bog iron ore, among others, in the Łososina valley [3].

The area is characterized by the alternation of concave and convex forms as well as elevations with different relative heights [2]. Altitudes in the catchment range from 188 to $447 \mathrm{~m}$. (Fig. 1). The Biała Nida catchment area is closed with watershed of the 2 nd and 
3rd order, and the main tributaries of the river are Łososina, Lipnica, Jedlinica, Kwilinka and Hutka. The northern part of the studied area is dominated by soils with low fertility and humus content, while the southern part is dominated by rendzinas [2]. There are two landscape parks in the analysed area, seven nature reserves, Natura 2000 and Protected Landscape Areas [4].

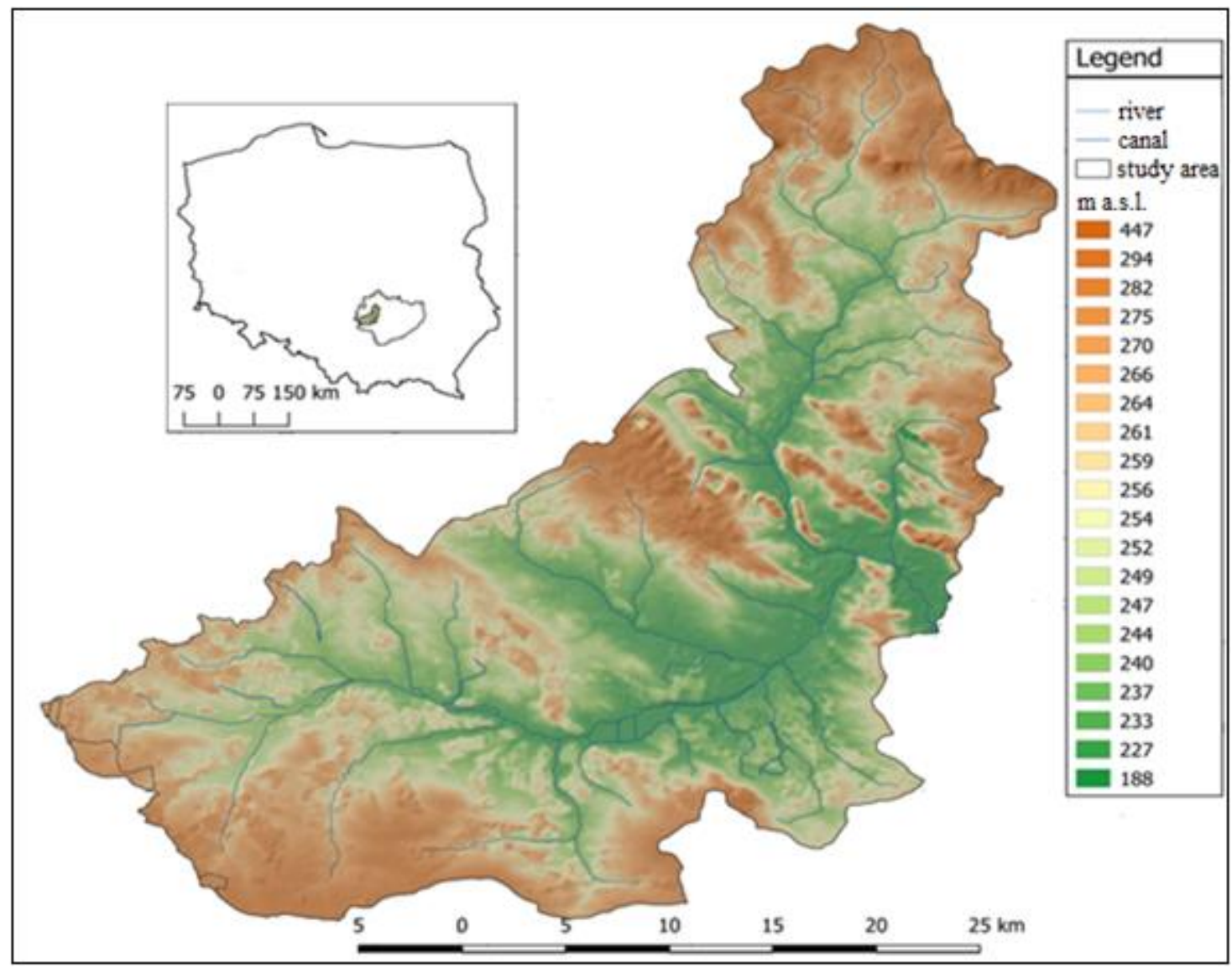

Figure 1. Digital terrain model of the Biała Nida river catchment.

\section{AIM OF THE STUDY AND METHODS}

The aim of this study was to identify changes in land use and land cover occurring in the catchment area of the Biała Nida since the beginning of the 19th century, as well as an attempt to determine the causes of these changes. The analyzed changes were related to such land use forms as forest areas, water reservoirs, marshlands, areas covered with grass vegetation, arable lands, built-up areas, watercourses, roads and railroads.

The essence of research was also to determine how these changes may take place in the near future [4]. The scope of study included analysis of data obtained as a result of objects vectorization, located on historical cartographic materials (Table 1; Fig. 2). The work uses the geographical information system tool - QGIS 3.10.4.

The usefulness of archival maps depends on the quality of their processing from analogue to digital format [5]. Research of land use changes began with the calibration of the four oldest topographic maps. Transformation of coordinates from the pixel system to the "1992" geodetic coordinate system was carried out using characteristic reference points, e.g. road crossings, bridges, churches, and mills. The older ones, created before the 19th 
century and some from the first half of the 19th century, were not prepared on the basis of the surveying grid, which makes them unreliable [4], [5], [6].

Table 1. Cartographic materials used in the stud.

\begin{tabular}{|c|c|c|c|c|}
\hline Time cutting & $\begin{array}{c}\text { Date } \\
\text { of issue }\end{array}$ & Type of data & Scale & Map \\
\hline the beginning of the $19^{\text {th }} \mathrm{c}$. & 1808 & raster & $1: 288000$ & Carte von West-Gallizien \\
\hline half of the $19^{\text {th }} \mathrm{c}$. & 1843 & raster & $1: 126000$ & Mapa Kwatermistrzostwa \\
\hline the beginning of the $20^{\text {th }} \mathrm{c}$. & 1915 & raster & $1: 100000$ & $\begin{array}{c}\text { Karte des Westlichen } \\
\text { Russlands }\end{array}$ \\
\hline first half of the $20^{\text {th }} \mathrm{c}$. & $1934-1939$ & raster & $1: 100000$ & Mapa Taktyczna Polski \\
\hline second half of the $20^{\text {th }} \mathrm{c}$. & $1966-1975$ & raster WMS & $1: 50000$ & Mapa Topograficzna \\
\hline the end of the $20^{\text {th }} \mathrm{c}$. & $1991-1998$ & raster WMS & $1: 50000$ & Mapa Topograficzna \\
\hline the beginning of the $21^{\text {st }} \mathrm{c}$. & 2019 & vector & - & BDOT10k \\
\hline
\end{tabular}

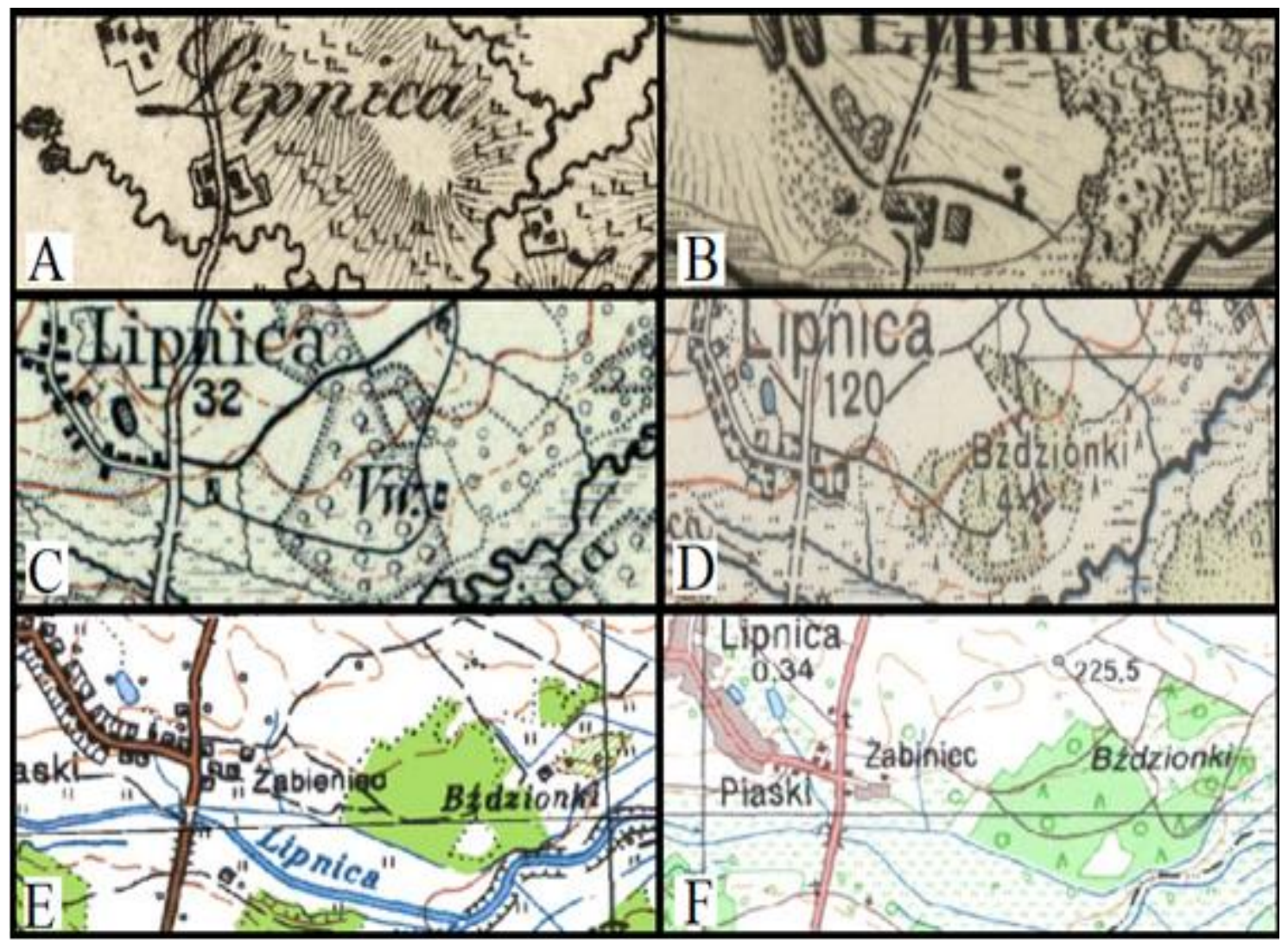

Figure 2. Cartographic materials used in the study: A - Carte von West-Gallizien, B - Mapa Kwatermistrzostwa, C - Karte des Westlichen Russlands, D - Mapa Taktyczna Polski [http://igrek.amzp.pl] , E - Mapa Topograficzna, F - Mapa Topograficzna [https://mapy.geoportal.gov.pl]

They can be a source of information about the existence of certain environment elements, e.g. forests, but they should be viewed with some distance as they are not fully cartometric [5]. In case of maps that do not follow the cartometric rules, a transformation called spline function (TPS) was applied, in which the image was distorted, but the control points coincided very well with the reference layer. The calibration of the 20th century maps was performed using a second-order polynomial transformation [5], [7]. The next stage of work was data analysis. After the map digitization was completed, the area of polygon features and the length of line features were calculated [4], [5]. 


\section{RESULTS}

The result of spatial analysis indicates that in 1808 non-forested areas (arable land, meadows, pastures, wooded areas, shrubs or wastelands) constituted about $58 \%$ of the Biała Nida catchment area (Table 2). Forests then occupied 41.5\% [4]. Areas located in the northern part were ore-bearing. Documents and names of some villages such as Ruda Zajączkowska, Hucisko, Kuźniaki prove the existence of industrial settlements in this area. The wood obtained from vast stretches of forest was used to produce charcoal, which was used to fuel steel furnaces [3], [4]. While in the southern part of catchment area there were favorable conditions for agricultural development.

Built-up areas and water reservoirs at that time constituted a minor share in the land use structure. The length of watercourses in 1808 was over $382 \mathrm{~km}$. Only the main roads were marked on the topographic map from the beginning of the 19th century. The vast majority of these roads were located in the southern part of catchment area and ran through the only town in studied area - Małogoszcz [4]. The town used to be an important trade center where the main transport routes crossed [4], [8].

Table 2. Structure of land use in the Biała Nida catchment in 1808-2019.

\begin{tabular}{|l|l|l|l|l|l|l|l|}
\hline Type of land use & 1808 & 1843 & 1915 & $1934-1939$ & $1966-1975$ & $1991-1998$ & 2019 \\
\hline forests $\left[\mathrm{km}^{2}\right]$ & 423.98 & 399.68 & 322.83 & 255.01 & 275.42 & 323.31 & 375.56 \\
\hline arable land $\left[\mathrm{km}^{2}\right]$ & - & 486.91 & 503.34 & 600.28 & 597.67 & 504.76 & 378.24 \\
\hline $\begin{array}{l}\text { meadows and } \\
\text { pastures }\left[\mathrm{km}^{2}\right]\end{array}$ & - & 124.37 & 175.11 & 138.47 & 121.94 & 164.81 & 216.42 \\
\hline $\begin{array}{l}\text { water reservoirs } \\
{\left[\mathrm{km}^{2}\right]}\end{array}$ & 1.90 & 2.04 & 4.14 & 8.74 & 6.69 & 7.38 & 9.26 \\
\hline wetlands $\left[\mathrm{km}^{2}\right]$ & - & 82.15 & 56.63 & 23.90 & 20.57 & 19.44 & 11.94 \\
\hline built-up areas $\left[\mathrm{km}^{2}\right]$ & 4.52 & 7.88 & 15.46 & 18.38 & 19.16 & 20.62 & 41.40 \\
\hline watercourses $[\mathrm{km}]$ & 382.05 & 410.14 & 577.25 & 576.16 & 1052.85 & 1243.84 & 1565.08 \\
\hline roads $[\mathrm{km}]$ & 149.56 & 2017.13 & 2090.72 & 2249.32 & 3196.96 & 4026.78 & 4743.88 \\
\hline railway lines $[\mathrm{km}]$ & - & - & 28.60 & 28.60 & 31.44 & 31.44 & 31.44 \\
\hline
\end{tabular}

The state policy at that time was to transform forests into arable land and to dispose of state property. The abolition of serfdom in 1864 after the January Uprising in the lands of Russian partition was an important factor in changes in land use. Forests were sold and cut down, wood was used to rebuild houses and farm buildings burned during the uprising [14], and land was used for agricultural production [15]. In 1915, farmland accounted for about $49 \%$. At the beginning of the 20th century, the share of built-up areas in the land use structure in the Biała Nida catchment area increased to $1.5 \%$.

The nature of built-up areas changed to a more compact one. In addition, two railroad lines were built in the catchment area. The decrease of swamps, bogs and marshes to approximately $57 \mathrm{~km} 2$ was mainly the result of drainage and increasing arable land area. The length of watercourses at the beginning of the 20th century increased to just over 577 $\mathrm{km}$. Numerous water reservoirs were created during this period, most of which were intended to serve as fish ponds. Forested areas between 1934 and 1939 occupied only $25 \%$ of studied area (Fig. 4). Deforestation may have been caused by the further conversion of forests into arable land and the use of wood for industry and construction, growing branches of the economy in the reborn People Republic of Poland 


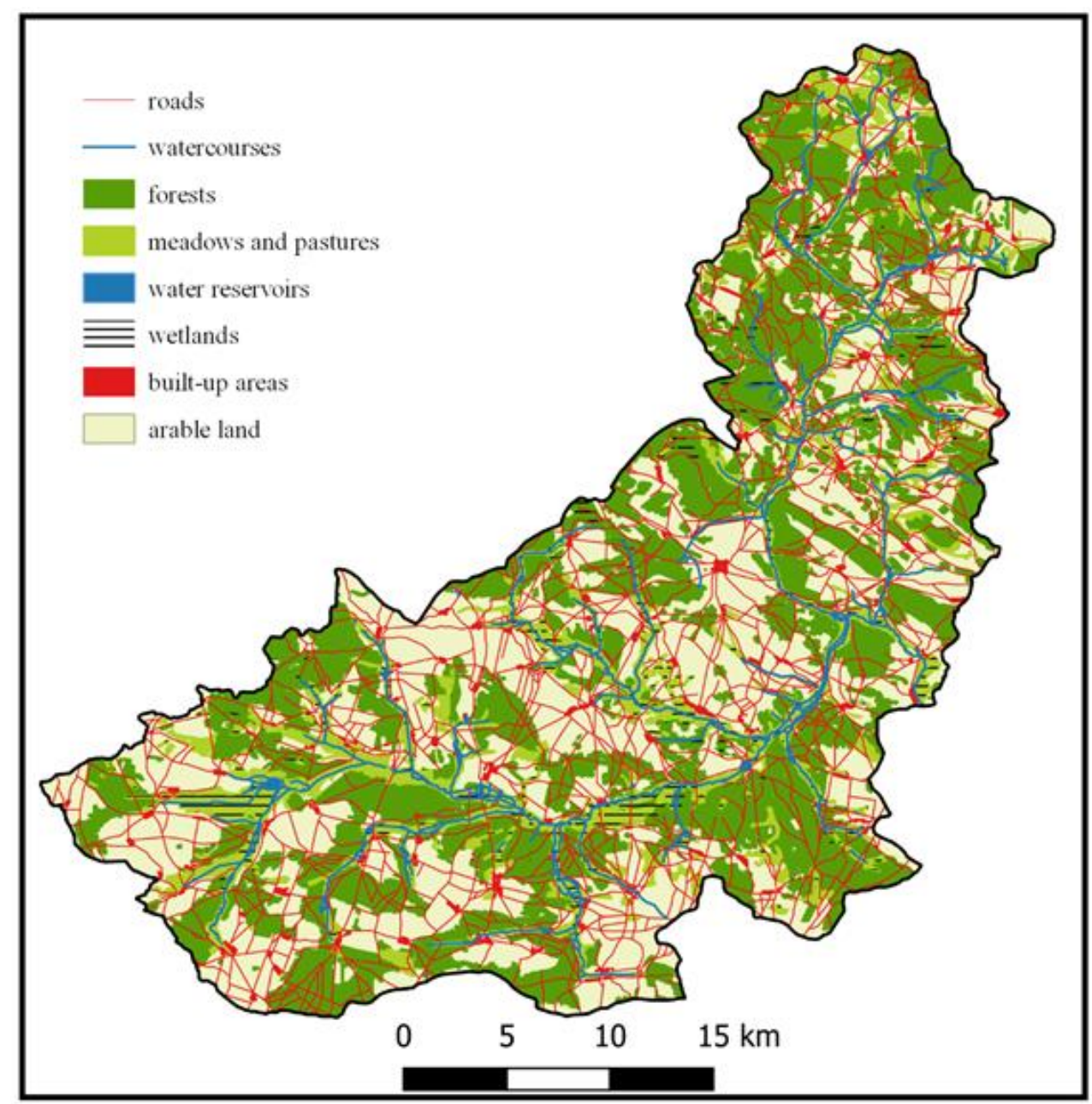

Figure 3. Land use of the Biała Nida catchement in 1843.

During this period, the highest share of arable land in the land use structure (about 59\%) was recorded. Meadows and pastures constituted about $14 \%$ of the studied area. At the end of the first half of the 20th century, not only forests, but also meadows and pastures were converted into arable land. Small areas of land designated for pastures and large numbers of livestock meant that livestock often had to graze on grassy baulks or in ditches. Many villages, especially in the northern and eastern part of the studied area, acquired a character of stretching compact buildings on both sides of the road. The analysis of cartographic reports from 1934-1939 indicates a 1.8\% share of developed areas in the land use structure. The vehicular road network was slightly expanded compared to the 1915 status. In 1934-1939, wetlands covered only less than $24 \mathrm{~km} 2$. The share of water reservoirs in the land use structure increased considerably and the length of water courses decreased [4]. 


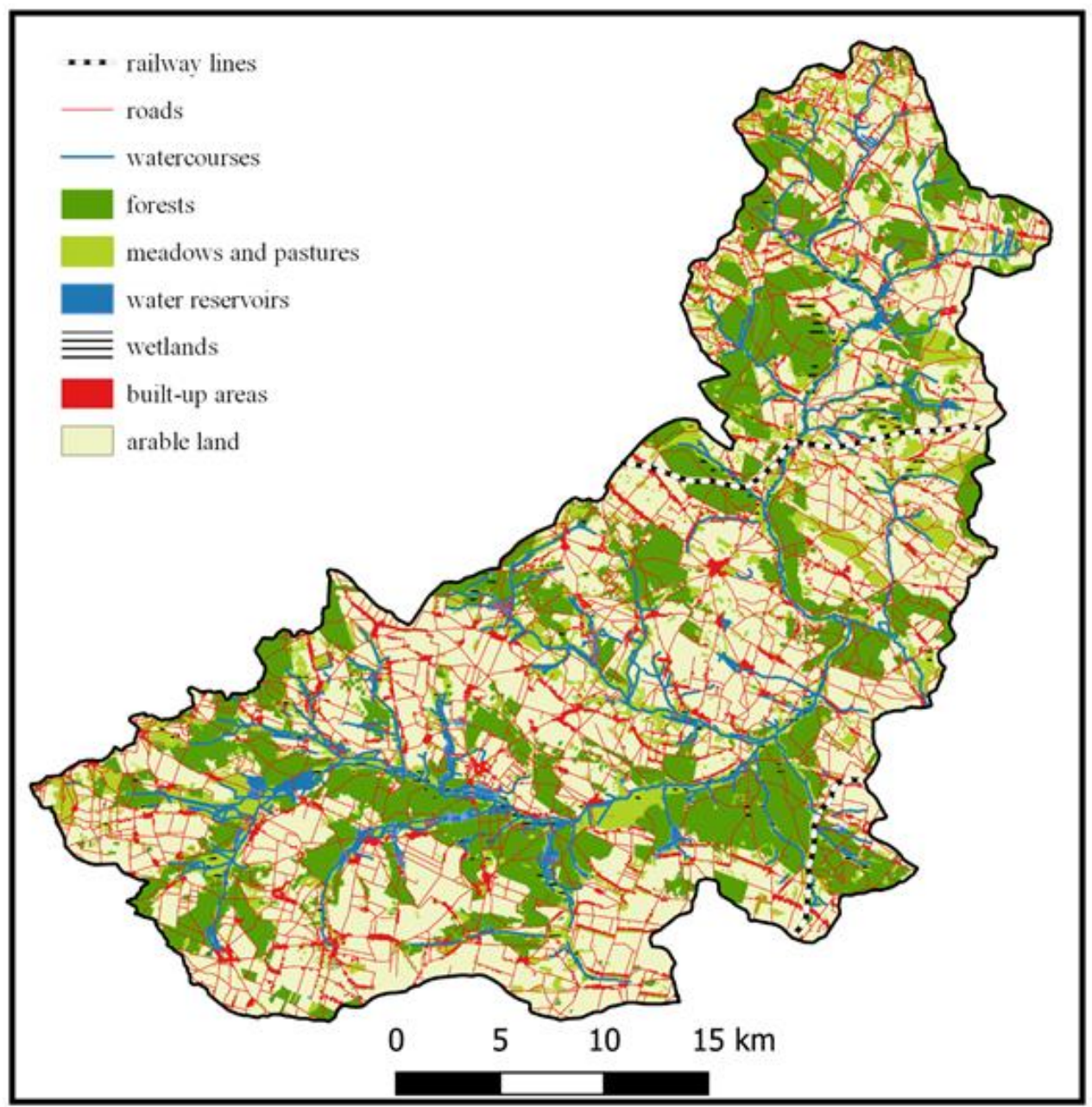

Figure 4. Land use of the Biała Nida catchement in the years 1934-1939

In the second half of the 20th century, forest coverage in the Biała Nida catchment area began to gradually increase. In a study from 1966-1975, forested areas accounted for 27\%. During the Second World War, forest areas were devastated. In post-war Poland, forest policy led to an increase in forest cover [4], [15]. In the second half of the 20th century the amount of arable land in the Biała Nida catchment area began to decrease. According to the topographic map prepared in 1966-1975, arable land constituted 58.5\%. In the central part of catchment, three large industrial plants were established, in which work became for people an alternative to work in agriculture.

In the second half of the 20th century, the area of built-up land in the Biała Nida catchment area increased to $1.9 \%$. A high concentration of buildings is characterized by the northern part of studied area, where mining industry plants were established. In this period a railroad connection with the cement plant at Małogoszcz was also built. After the Second World War, the road network became very dense $(3197 \mathrm{~km})$. The river network along with drainage ditches was almost $1053 \mathrm{~km}$ long. The construction of many ditches and drainage channels (melioration) may have been the reason for significant difference in the length of watercourses, which occurred in only about thirty years. Wetlands were drained on a massive scale and then used as arable land or for buildings. The share of forests in the land use structure in the following years increased to $31.7 \%$ (Fig. 5). New forest areas appeared mainly in the eastern part of the Biała Nida catchment where weak or incipient soils dominate. 


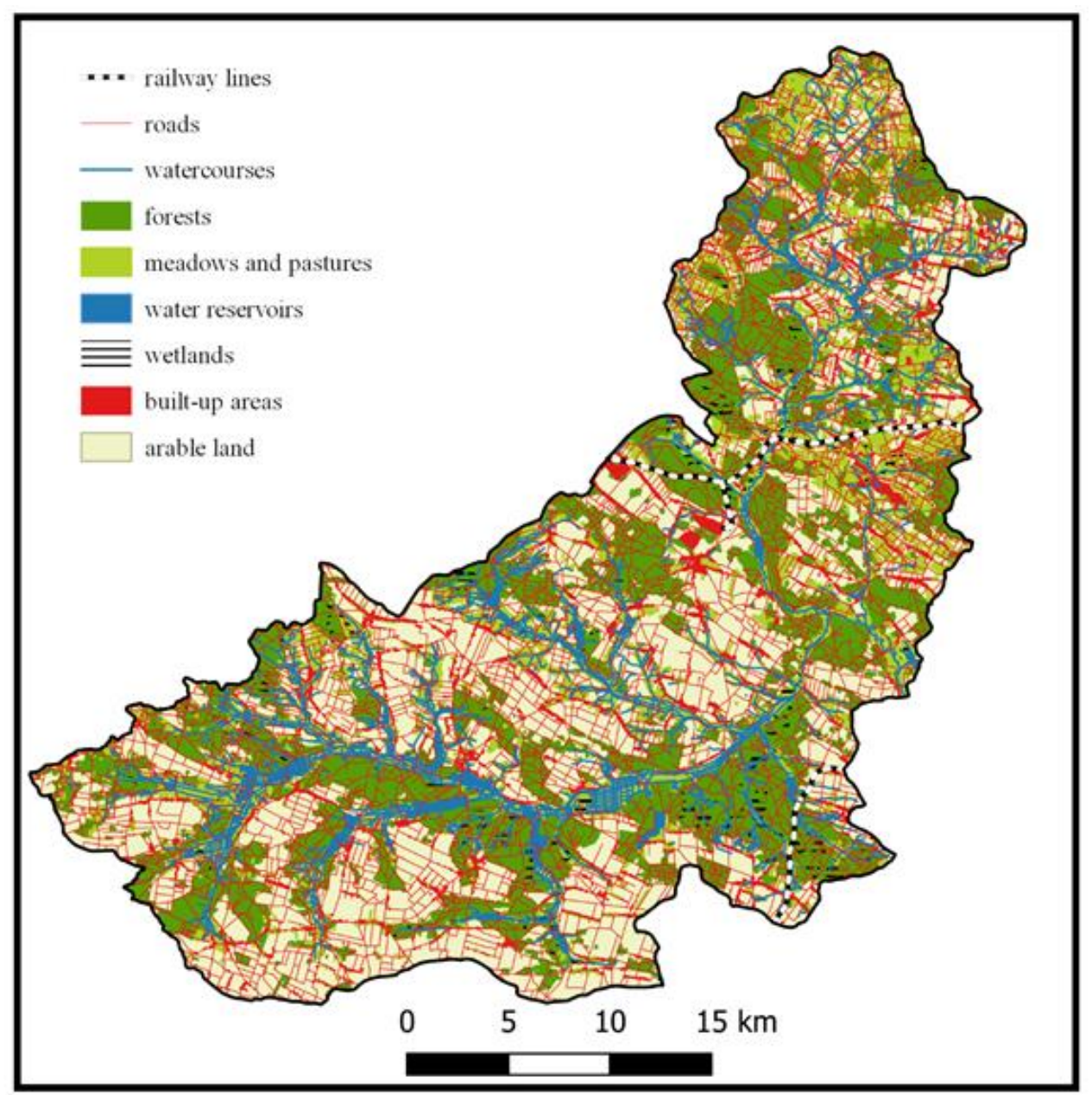

Figure 5. Land use of the Biała Nida catchement in the years 1991-1998.

The establishment of large industrial plants, e.g. the limestone mine in Miedzianka, contributed to the drainage of analyzed land. There is a clear division between the agricultural southern part of catchment and the non-agricultural northern part. The share of meadows and pastures in the land use structure increased to just over $16 \%$. It can be assumed that areas, which were previously arable land, became wasteland. At the end of the 20th century, built-up areas still occupied a small area (about 2\%). The following years brought a deepening of the expansion of drainage ditches and channels network. The length of watercourses increased to over $1244 \mathrm{~km}$. The area of water reservoirs, which were created mainly in places of mine excavations, also increased. At the beginning of the 21 st century, forest cover in the Biała Nida catchment area increased to almost $37 \%$ (Fig. 6).

Arable land accounted for about $37 \%$ in 2019. Whereas the area covered by grassland vegetation increased significantly [4], mainly due to fallow areas [5]. The area of builtup land (about $4 \%)$ and the length of roads $(4744 \mathrm{~km})$ also increased. Spatial analysis of watercourses and water reservoirs shows that the system of drainage ditches has been expanded and new water reservoirs have been created (mainly for retention as well as for tourist and recreational purposes) [4]. 


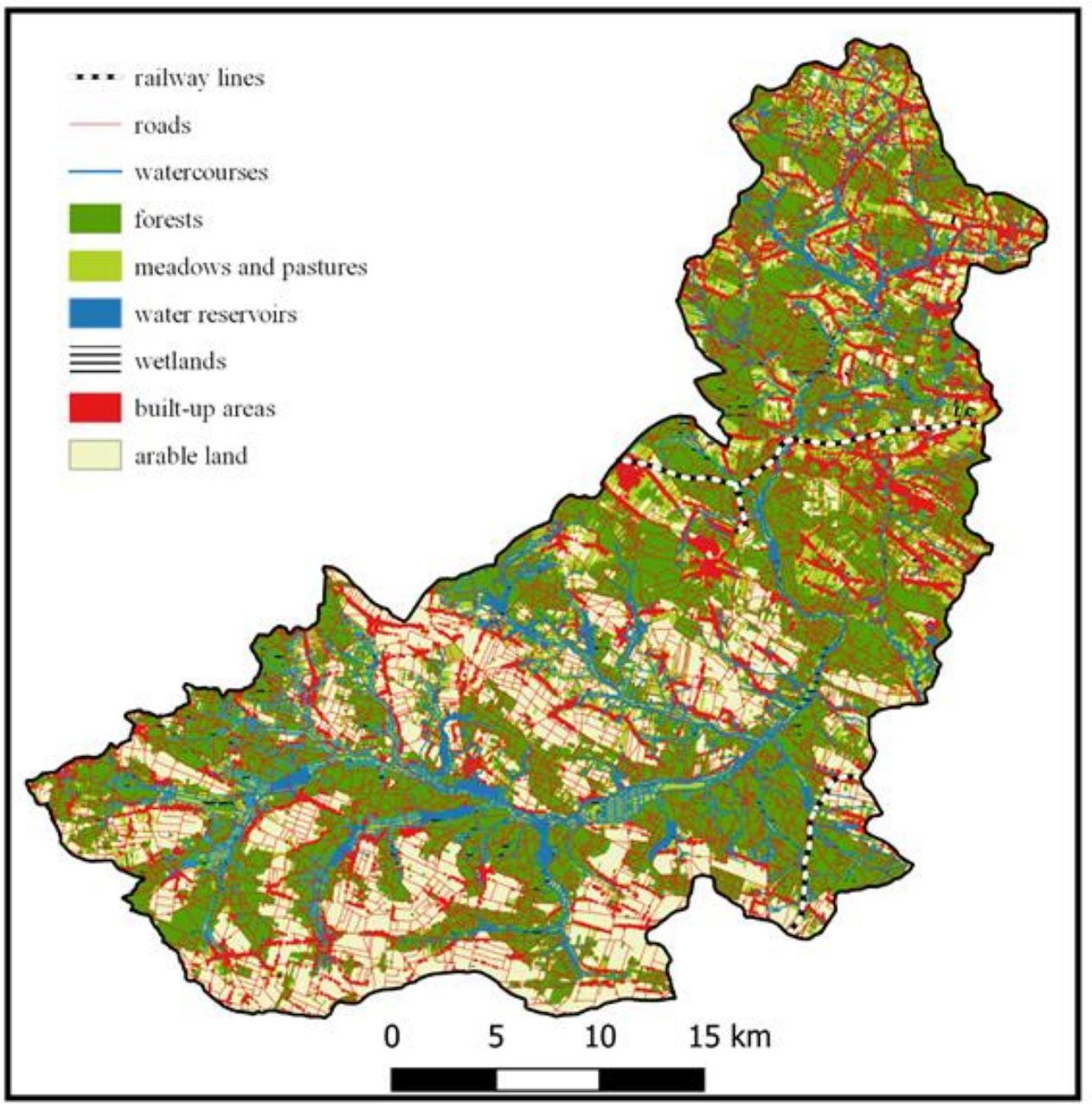

Figure 6. Land use of the Biała Nida catchement in 2019.

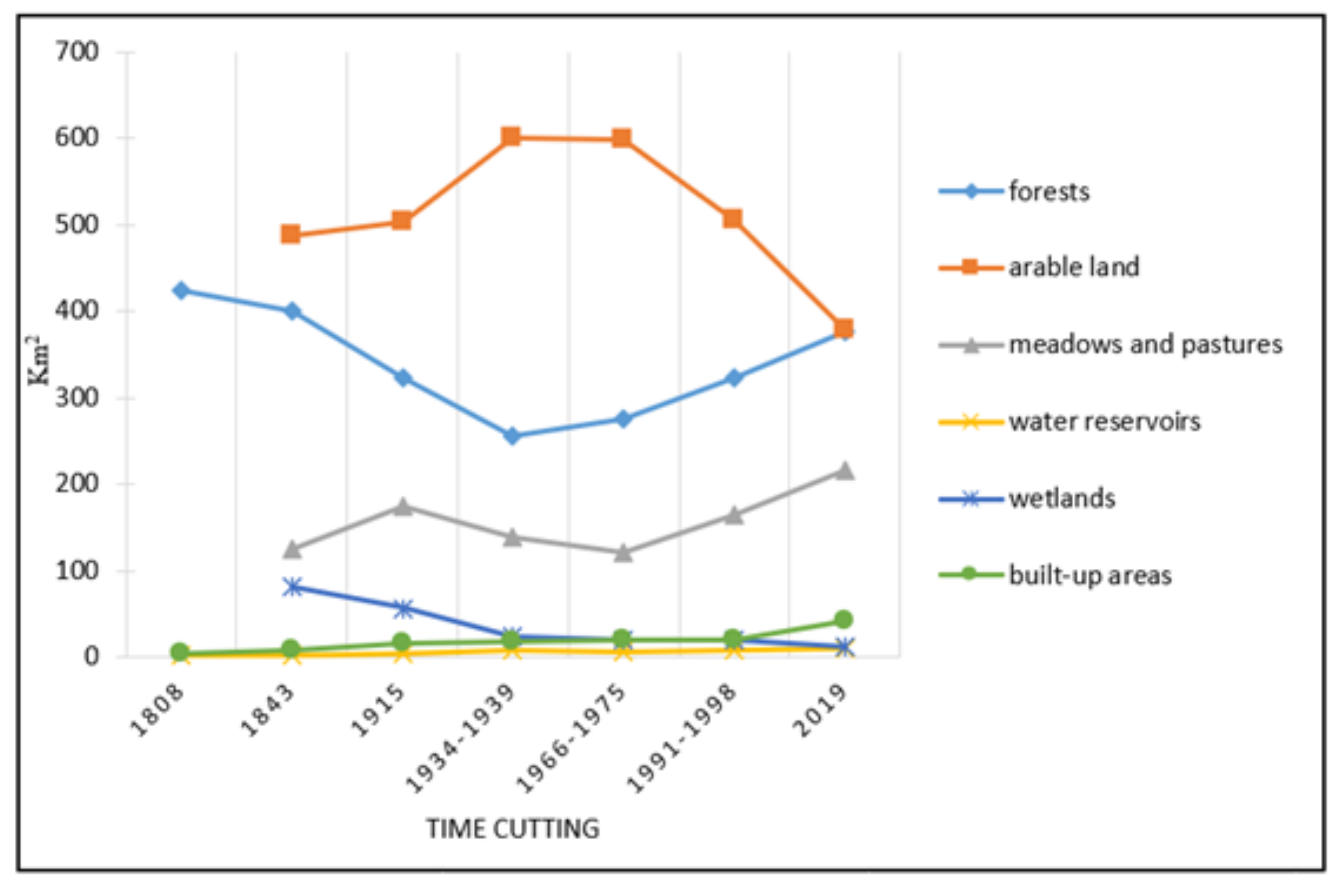

Figure 7. Changes in the structure of land use in the Biała Nida catchment 


\section{CONCLUSIONS}

Archival topographic maps can be used in studies on land use changes, but not without criticism. The result of spatial analyses depends largely on accuracy, legibility, scale and generalization degree of the cartographic material used, as well as on the quality of calibration and vectorization performed. These factors can completely distort the perception of changes occurring in the landscape as they affect the geometry of topographic signs used and their position [4], [16].

Changes in land use during the time periods studied were influenced primarily by political and socio-economic transformations. More intensive transformations in land use structure took place in the northern part of the Biała Nida catchment. The greatest changes occurred in the proportion of arable land and forests. After the Second World War, there was a reversal of the trend to increase the arable land area at the expense of forests. It can be predicted that in the future forest areas will not be transformed into arable land. In addition, in recent years there has been a tendency to convert poor quality agricultural land, areas located on steep slopes and degraded land into forested areas and it is expected that this tendency will continue in the coming years. Due to drainage works in the catchment area, the length of watercourses has definitely increased, while the area of wetlands has decreased [4].

\section{REFERENCES}

[1] Kondracki J., Geografia regionalna Polski, Wydawnictwo Naukowe PWN, Warszawa, pp 257-278, 2001.

[2] Ciupa T., Współczesny transport fluwialny w zlewni Białej Nidy, Kielce, 1991.

[3] Kosik E., We włościańskim Mniowie: [monografia historyczno-gospodarcza gminy Mniów], Kielce, 1999.

[4] Biskupska A., Kartograficzny obraz zmian użytkowania ziemi w zlewni Białej Nidy od końca XVIII wieku. Maszynopis pracy magisterskiej, Archiwum WNŚiP UJK, 2020.

[5] Biskupska A., Zmiany użytkowania gruntów w gminie Małogoszcz w latach 1808-2019. Maszynopis pracy magisterskiej, Archiwum WIŚiG UR, 2020.

[6] Czerny A., Cebrykow P., Krukowski M., Łoboda A., Kuna J., Rzucidło A., Meksuła M., Grzechnik L., Kowalski P. Dawne mapy topograficzne w badaniach geograficzno-historycznych. Lublin, 2015.

[7] Affek A., Kalibracja map historycznych z zastosowaniem GIS. Prace Komisji Krajobrazu Kulturowego Nr 16. Sosnowiec, pp 48-62, 2012.

[8] Kosik E., W kasztelańskim Małogoszczu: [monografia historyczno-gospodarcza Małogoszcza i okolicy]. Kielce, 1994.

[9] Przepióra, P., Król, G., Kalicki, T., Anhtropogenic changes of Kamionka Valley based on carthographic and historical sources. Abstract book and field guide - Geoarcheology of river valleys. Uniwersytet Jana Kochanowskiego w Kielcach, Kielce, pp 108-109, 2013.

[10] Kalicki T., Fularczyk K., Zmiany biegu koryta Krasnej (Świętokrzystkie) w oparciu o dane kartograficzne i geologiczne, Acta Universitatis Lodziensis, Folia Geographica Physica 17, pp 15-23, 2018.

[11] Nowak E., Czaja K., Kalicki T., Influence of development and collapse of the Old Polish District on environmental changes and land use during the last 200 years: case study from Czarna Konecka River basin (Holy Cross MTS. Region, Poland), Acta Geobalcanica 7, pp 19-25, 2020. 
[12] Pazdura J. (red.), Katalog zabytków budownictwa przemysłowego w Polsce, Tom II Województwo Kieleckie. Wydawnictwo Polskiej Akademii Nauk, Wrocław - Warszawa, 1959.

[13] Chrabąszcz, M., Kalicki, T., Przepióra, P., Frączek, M., Zmiany koryta dolnej i środkowej Wiernej Rzeki od XVIII wieku. Folia Geographica. Physica 16, pp 5-13, 2017.

[14] Jastrzębski C., Bitwa pod Małogoszczem 1863, Małogoszcz, 2013.

[15] Poławski Z.F., Zmiany użytkowania ziemi w Polsce w ostatnich dwóch stuleciach. Teledetekcja Środowiska 42, Warszawa, 2009.

[16] Wolski J., Błędy i niepewności w procesie tworzenia map numerycznych. Prace Komisji Krajobrazu Kulturowego Nr 16. Sosnowiec, pp 15-32, 2012. 